\title{
Mesothelioma and asbestosis in a young woman following occupational asbestos exposure: Short latency and long survival: Case Report
}

\author{
Enrique Bitchatchi ${ }^{1 *}$, Klaus Kayser $^{2}$, Marina Perelman ${ }^{3}$, Elihu D Richter $^{1}$
}

\begin{abstract}
A 27-year-old female white-collar worker was diagnosed in 1998 with mesothelioma eight and one-half years following first exposure as a bystander to debris in a site in which asbestos-containing building materials were being dismantled and rebuilding work took place. Prodromal back pain had been present for a year and a half. She underwent extrapleural pneumectomy and received an intrapleural infusion of cisplatin post-operatively. Exposure to asbestos was verified by contemporary reports and lung biopsy, which demonstrated asbestos bodies and microscopic interstitial fibrosis -conforming evidence for asbestosis. The patient is alive and well 12 years after diagnosis and 14 years after onset of symptoms. The combination of an extremely short latency period and long survival following occupational exposure to asbestos dust is unique.
\end{abstract}

\section{Case Presentation}

A 27-year-old Israeli born woman presented with upper back pain and shortness of breath, diagnosed as Tietze's syndrome in 1996. The pain radiated to her right flank and impeded rest. Chest radiography performed 6 months following presentation was negative. In the 18 months following onset of complaints the patient underwent examinations at orthopedic and pain clinics, including spine (D6-L2) computed tomography (CT), and physical therapy, but showed no improvement. The tomography, performed nine months after onset of symptoms, revealed a thickening process anterior to D9. Three months later, chest radiography showed minimal interstitial changes including few peripheral small opacities on the lower right field. These signs were overlooked. The left lung was clear and showed no pleural or parenchymal abnormalities. Forced expiratory volume in one second $\left(\mathrm{FEV}_{1}\right)$ and forced vital capacity (FVC) were $95 \%$ and $96 \%$ the predicted value, respectively. Fourteen months after the onset of symptoms, she began losing weight and appetite. CT of the abdomen and chest and focused magnetic resonance imaging

\footnotetext{
* Correspondence: eboccupenviron@gmail.com

'Unit of Occupational and Environmental Medicine, Braun School of Public Health and Community Medicine, Faculty of Medicine, Hebrew University, Jerusalem, Israel

Full list of author information is available at the end of the article
}

showed right pleural thickening and $10 \mathrm{~mm}$ focal ipsilateral lung nodules. Tissue biopsy from transpleural thoracoscopy and subsequent complete right extrapleural pneumonectomy indicated mesothelioma and right after surgery, she received an intrapleural infusion of cisplatin. Stage was T1b N0 M0 (according to International Mesothelioma Interest Group 1995). No calcified pleural plaques were found. Three years following surgery her best FVC was recorded as $53 \%$ the expected value. Five years after diagnosis, a cardiopulmonary function test indicated restrictive postpneumonectomy pattern, excellent functional compensation and preserved cardiac reserve; however, the test (aimed at $15 \mathrm{Watts} / \mathrm{min}$ performance) was interrupted due to dyspnea, which was attributed to suboptimal endurance. Fourteen years from presentation, the patient is in remission, she is working and has completed a successful pregnancy. Histological examination indicated tubopapillary type mesothelioma -Figure 1- (verified by the US-Canadian Mesothelioma Panel- formal correspondence exchange with oncology institute; signed by Panel's chairman in 1997, Dr. A. Churg). Scattered bronchioles showed mild fibrosis without extension into adjacent alveoli. The degree of fibrosis was classified as grade 1 (severity- 1 ; extent-1) according to NIOSH/CAP criteria for pathologic grading of asbestosis [1]. Quantitative light microscopic count of cytospinned asbestos bodies extracted 


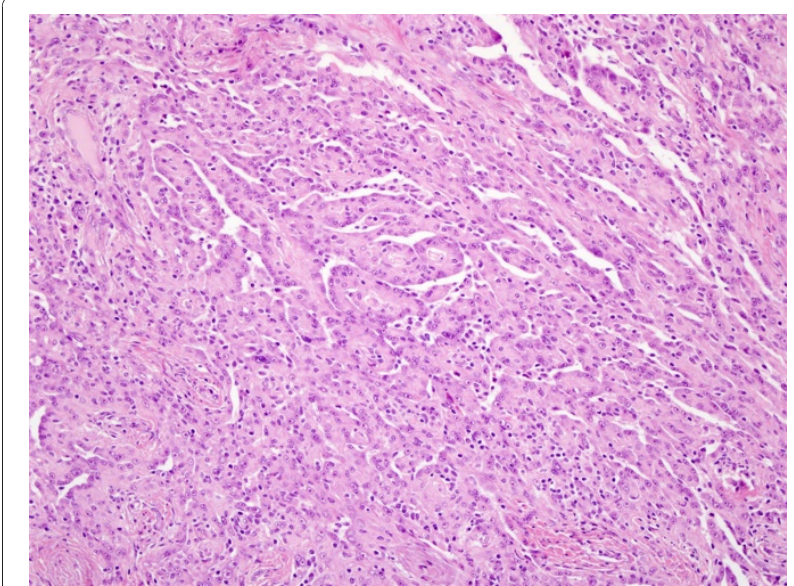

Figure 1 Malignant mesothelioma, epithelioid variant. The tumor exhibits papillary and tubular pattern (H\&E, original magnification $\times 200$ )

by wet digestion yielded 305 asbestos bodies/g wet lung tissue, 19 times our reference value [2,3] (Figure 2).

\section{Exposure history}

The patient recalled her first exposure to dusts during intensive demolition/construction work at her workplace, an airport office. The work-the first job in her life, when drafted into the military- began in 1989 when she was 20 years of age, and continued for approximately 6 years. Co-workers under judicial investigation recalled seeing asbestos wallboard and debris at the site. Her work routine included excessive work hours, sleeping on site and irregular work shifts (approximately 5000 hours of passive, intermittent, exposure to airborne dust). During the $4^{\text {th }}$ calendar year, she became pregnant and got post labor permission for 3 months. No measurements of concentrations of asbestos, constituents of environmental tobacco smoke, man-madevitreous-fibers and respirable particulate, dusts or gasses were carried out. Information was not available on the mix of fibers in the dusts during demolition at her work site. However, a newspaper article in 1989, contemporary with exposure, reported that Dr Joseph Ribak, then chief of occupational medicine of the major national health care provider, specified that her work site was one of several with acoustic ceilings sprayed with asbestos fibers [4]. We also know that in Israel, the fiber mix of most asbestos construction products was approximately $90 \%$ chrysotile $-10 \%$ amphiboles [5].

The patient's past exposure history was otherwise unremarkable, with negative answers to directed questions on exposures as bystanders to asbestos or talc in family, work, home, or hobbies. Her father worked as a police officer and her mother as a housewife, partially self-employed in sewing jobs. No other working adult lived in the household. Based on an official list of all her past addresses, we double-checked those obtained by detailed anamnesis confirming no history of residency near asbestos cement plants or brake lining plants from infancy onward. She denied having contact with Thorotrast.

\section{Discussion}

To the best of our knowledge, the seven-year latency period between first exposure and complaints, and 8.5 years (14 months lapsed between symptoms and diagnosis) to diagnosis of mesothelioma is the shortest ever reported in an adult. The case for this conclusion rests on both tissular and independent ascertainment of

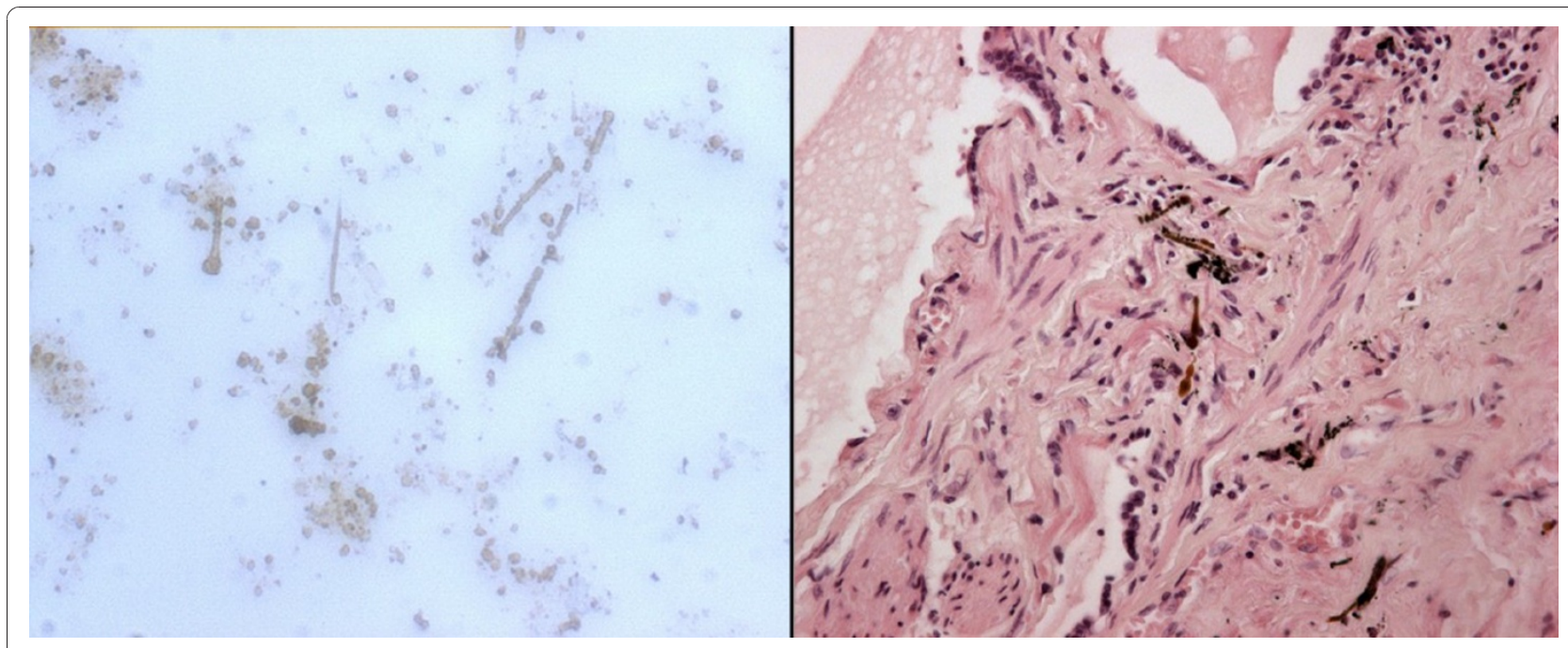

Figure 2 Asbestos bodies (I) and lung tissue with asbestos bodies (r). 
exposure, notably the contemporary report by occupational health authorities specifically referring to asbestos dust exposures at the patient's workplace. The light microscopy technique, with a $60 \times$ objective lens is too low a magnification to detect the vast majority of asbestos fibers retained. The moderately elevated concentration above background -in the patient's resected lung is supportive of her past work exposures causing mesothelioma [6-13], given the absence of any other known source. The finding of asbestosis is a strong confirmation that she had substantial asbestos exposure.

We note that the demonstration of several asbestos bodies in a light micrograph of lung tissue when combined with interstitial fibrosis on histology is sufficient also for a diagnosis of asbestosis using standard NIOSH/ College of American Pathology criteria [1]. Her unilateral imaging features are not in agreement with pulmonary fibrosis as set by current criteria. However, histologically proved asbestosis has been recognized elsewhere, despite lack of abnormalities on a CT scan [14]. Our case represents indeed a deviant from common acceptance of an incubation of tens of years to diagnosis of this pneumoconiosis $[15,16]$, with a minimum latency of 10 years [17]. The occupational history and the discovery of asbestos facts in conjunction with the histopathologic detection of interstitial fibrosis make the hypothesis for a "spontaneous case" for mesothelioma most unlikely.

Davis and Rall published a table, which specified that the latent period for cancer in persons with workplace exposures to high volume carcinogens can range from 4 to 40 years [18]. A study from Poland reported 16 cases of pleural mesothelioma found among a cohort exposed from 1987 to 1997. Four of the patients were employed for periods ranging from 3.5 months to five years. Two of the four had latency periods of 11-12 years from onset of occupational exposure. These four patients had occupational and prior residential exposures associated with massive use of commonly available asbestoscement wastes as road surface material [19]. Our report along with that from Poland calls into question the general consensus that latencies for mesothelioma under 10 years are improbable.

An absence of calcified pleural plaques in our patient may imply shorter latency since exposure [20,21]. Animal experiments with implantation of asbestos or other fibers in the pleura or peritoneum show that the latent period shortens as fiber dose is increased and lengthens as the dose of fiber is reduced [20]. The present report indicates that high prior exposures, particularly at younger ages, may result in shortened induction periods, in keeping with classic observations on increased dose and shortened latency [22-24].

Individuals with direct exposures associated with the construction trades are apt to be the most heavily exposed [25]. During pregnancy, the physiological augmentation of minute ventilation leads to a greater dust burden into lung parenchyma. As with ionizing radiation, the earlier the age at exposure, the shorter the latency period for asbestos related cancers [26]. Worker cohort studies indicate that earlier age of exposure predicts incremental lifelong adjusted risks for mesothelioma $[27,28]$ and persons near asbestos work are at risk of "bystander exposure" [29,30].

In comparison with mixed and sarcomatoid, the epithelial cell type described in our patient, predicts better prognosis $[31,32]$.

\section{Conclusions}

This patient was diagnosed with asbestosis and mesothelioma eight and one-half years following asbestos exposure independently reported at the time of its occurrence. She has survived twelve years post diagnosis and resection. Although unexpected longevity has been reported elsewhere [33,34], we have no explanation for the long survival despite the very short latency.

\section{Consent}

Written informed consent was obtained from the patient for publication of this case report and any accompanying images. A copy of the written consent is available for review by the Editor-in-Chief of this journal.

\section{Abbreviations}

NIOSH: National Institute for Occupational Health and Safety; CAP: College of American Pathologists; Other abbreviations were defined in the text.

\section{Acknowledgements}

The authors thank Alf Fischbein and Arthur L. Frank for their advice and encouragement.

\section{Author details}

${ }^{1}$ Unit of Occupational and Environmental Medicine, Braun School of Public Health and Community Medicine, Faculty of Medicine, Hebrew University, Jerusalem, Israel. ${ }^{2}$ Telepathology Consultation Center at the Institute of Pathology Charité Medical Faculty of the Humboldt-University, Berlin, Germany. ${ }^{3}$ Department of Pathology, Sheba Medical Center, Tel Hashomer, Israel.

\section{Authors' contributions}

EB saw the patient 4 years after the pneumonectomy, then carried out the clinical and epidemiologic investigation and wrote most of the drafts. KK carried out the fiber counts in his laboratory; he performed histological analysis including asbestosis grading. MP contributed pursuing further histological examinations and revisions as to set asbestosis classification as well. ED revised and helped rewrite the drafts and added material to the discussion. All authors read and approved the final manuscript.

\section{Competing interests}

The authors declare they have no competing interests, whether financial or non-financial. Leading author (EB) did act as expert witness appointed by the patient. The litigation ended in 2003. There will be no reopening of the judicial process.

Received: 17 November 2010 Accepted: 16 December 2010 Published: 16 December 2010 


\section{References}

1. Craighead JE, Abraham JL, Churg A, Green FH, Kleinerman J, Pratt PC, Seemayer TA, Vallyathan $V$, Weill H: The pathology of asbestos-associated diseases of the lungs and pleural cavities: diagnostic criteria and proposed grading schema. Report of the Pneumoconiosis Committee of the College of American Pathologists and the National Institute for Occupational Safety and Health. Arch Pathol Lab Med 1982, 106:544-96.

2. Kayser K, Becker C, Seeberg N, Gabius HJ: Quantitation of asbestos and asbestos-like fibers in human lung tissue by hot and wet ashing, and the significance of their presence for survival of lung carcinoma and mesothelioma patients. Lung Cancer 1999, 24:89-98.

3. Kayser K, Seemann C, Andre S, Kugler C, Becker C, Dong X, Kaltner H, Gabius HJ: Association of concentration of asbestos and asbestos-like fibers with the patient's survival and the binding capacity of lung parenchyma to galectin-1 and natural alpha-galactoside- and alphamannoside-binding immunoglobulin $\mathrm{G}$ subfractions from human serum. Pathol Res Pract 2000, 196:81-87.

4. Valentin A: End of asbestos era. Haaretz, Weekend Magazine; 1989, 12.

5. Richter ED: Asbestos exposure in Israel: Findings, issues and needs. Israel J Med Sci 1984, 20:89-97.

6. Gylseth B, Mowe G, Skaug V, Wannag A: Inorganic fibers in lung tissue from patients with pleural plaques or malignant mesothelioma. Scand J Work Environ Health 1981, 7:109-13.

7. Howel D, Gibbs A, Arblaster L, Swinburne L, Schweiger M, Renvoize E, Hatton P, Pooley F: Mineral fiber analysis and routes of exposure to asbestos in the development of mesothelioma in an English region. Occup Environ Med 1999, 56:51-8.

8. Karjalainen A, Nurminen M, Vanhala E, Vainio H, Anttila S: Pulmonary asbestos bodies and asbestos fibers as indicators of exposure. Scand J Work Environ Health 1996, 22:34-8.

9. McDonald JC Armstrong BG, Edwards CW, Gibbs AR, Lloyd HM, Pooley FD: Case-referent survey of young adults with mesothelioma: lung fiber analysis. Ann Occup Hyg 2001, 45:513-8.

10. Mowe G, Gylseth B, Hartveit F, Skaug V: Occupational asbestos exposure, lung-fiber concentration and latency time in malignant mesothelioma. Scand J Work Environ Health 1984, 10:293-8.

11. Pooley FD, Berry G, Rogers AJ: Mesothelioma - asbestos exposure and lung burden. Sci Publication Issued IARC Lyon 1989, 90:486-96.

12. Rodelsperger $\mathrm{K}$, Jockel KH, Pohlabeln H, Romer W, Woitowitz HJ: Asbestos and man-made vitreous fibers as risk factors for diffuse malignant mesothelioma: results from a German hospital-based case-control study. Am J Ind Med 2001, 39:262-75.

13. Srebro SH, Roggli VL, Samsa GP: Malignant mesothelioma associated with low pulmonary tissue asbestos burdens: a light and scanning electron microscopic analysis of 18 cases. Mod Pathol 1995, 8:614-21.

14. Paris C, Benichou J, Raffaelli C, Genevois A, Fournier L, Menard G, et al: Factors associated with early-stage pulmonary fibrosis as determined by high resolution computer tomography among persons occupationally exposed to asbestos. Sand J Work Environ Health 2004, 30:206-214

15. Balmes J: Occupational Lung Diseases. In Current Occupational and Environmental Medicine. 4 edition. Edited by: LaDou J. New York: McGrawHill; 2007:310-327.

16. Lanphear BP, Buncher CR: Latent period for malignant mesothelioma of occupational origin. J Occup Med 1992, 34:718-21.

17. Chahinian AP, Pass HI: Malignant Mesothelioma. In Cancer Medicine. Edited by: Kufe DW, Weichselbaum RR, Pollock RE, Basts Jr RC, Gansler TS, Holland JF, Frei E. American Cancer Society: BC Decker Hamilton; 2006:1447-61.

18. Davis DL, Rall DP: Risk Assessment for Disease Prevention. In Strategies for Public Health. Edited by: Lorenz K, Ng Y, Davis DL. Van Nostrand, Reinholt; 1981: [The table is cited in pp. 258-260, Davis DL, Secret History of the War on Cancer. New York: Basic Books; 2007:505].

19. Szeszenia-Dabrowska N, Wilczynska U, Szymczak W, Laskowicz K: Environmental exposure to asbestos in asbestos cement workers: a case of additional exposure from indiscriminate use of industrial wastes. Int J Occup Med Environ Health 1998, 11:171-7.

20. Parkes WR: Occupational lung disorders. 3 edition. Oxford: ButterworthHeinemann; 1994

21. Becklake MR: Occupational lung disease-past record and future trend using the asbestos case as an example. Clinical and Investigative Medicine $1983,6: 305-317$
22. Armenian HK, Lilienfeld AM: Distribution of incubation periods of neoplastic diseases. Am J Epidemiol 1974, 99:92-100.

23. Smith $P G$, Doll $R$ : Mortality among patients with ankylosing spondylitis after a single treatment course with X-rays. Br Med J (Clin Res Ed) 1982, 284:449-460

24. Whittemore AS: Age distribution of human cancer from carcinogenic exposure of various intensities. Am J Epidemiol 1977, 106:418-432.

25. Agency for Toxic Substances and Disease Registry (US): Case studies in environmental medicine Department of Health and Human Services. San Rafael, California; 1990.

26. Hall JC: Principles of Carcinogenesis. In Cancer: Principles and Practice of Oncology. 4 edition. Edited by: DeVita VT, Helman S. Rosenberg SA: Philadelphia: Lippincott; 1993:213-227.

27. National Research Council Scientific Report: Washington. D.C.: National Academy Press; 1984.

28. Peto J, Doll R, Hermon C, Binns W, Clayton R: Relationship of mortality to measures of environmental asbestos pollution in an asbestos textile factory. Ann Occup Hyg 1985, 29:305-355.

29. Ringen K, Englund A, Segal JL, McCann M, Lemen RA: Construction Workers. In Occupational Health: Recognizing and preventing work-related disease and injury. Edited by: Levy BS, Wegman DH. Philadelphia: Lippincott, Williams 2001:756.

30. Oliver LC: Asbestos in Public Buildings. In Environmental and Occupational Medicine. 2 edition. Edited by: Rom WN. Boston: Little, Brown and Company; 1992:293-300.

31. Robinson BWS, Musk AW, Lake RA: Malignant mesothelioma. Thelancet com 2005, 366:397-408

32. Becklake MR, Bagatin E, Neder JA: Asbestos-related diseases of the lungs and pleura: uses, trends and management over the last century. Int $J$ Tuberc Lung Dis 2007, 11:356-369.

33. Fischbein A, Suzuky Y, Selikoff IJ, Bekesi JG: Unexpected longevity of a patient with malignant pleural mesothelioma: report of a case. Cancer 1978, 42:1999-2000.

34. Neuman V, Müller KM, Fischer M: Malignant Mesothelioma-German mesothelioma register 1987-1999. Int Arch Occup Environ Health 2001, 74:383-395.

doi:10.1186/1746-1596-5-81

Cite this article as: Bitchatchi et al: Mesothelioma and asbestosis in a young woman following occupational asbestos exposure: Short latency and long survival: Case Report. Diagnostic Pathology 2010 5:81.

\section{Submit your next manuscript to BioMed Central and take full advantage of:}

- Convenient online submission

- Thorough peer review

- No space constraints or color figure charges

- Immediate publication on acceptance

- Inclusion in PubMed, CAS, Scopus and Google Scholar

- Research which is freely available for redistribution

Submit your manuscript at www.biomedcentral.com/submit
C) Biomed Central 